\title{
The Impact of Companies’ Size on E-Commerce Transaction Requirements: Case Study of Algerian Import Companies
}

\author{
Assia Djenouhat \\ Badji Mokhtar University, Annaba, Algeria
}

\begin{abstract}
The purpose of this paper is to investigate the impact of companies' size on e-commerce transaction requirements, by examining both companies’ components and companies’ partners and their relation with company's size. The paper is based on the analysis of 70 Algerian import companies through survey methodology. The findings indicate that large-sized companies respond strongly to all e-commerce transaction requirements, especially in the three companies' components; medium- and small-sized companies response to these requirements is less than large-sized companies. As a conclusion, companies’ size often reacts to the e-commerce transaction requirements.

Keywords: EC transaction requirements, Algerian import companies
\end{abstract}

\section{Background}

E-commerce is a new development in international commerce, or international trading. E-commerce retails the use of electronic platform in the exchange of goods and services; it encompasses the use of computer internet and other ICT, communication facilities to facilitate exchange, trading of goods and services. Recently, Algeria and China businesses have adopted this platform to trading among themselves. Although, this platform has not fully been embraced, this indicates that the use of the platform is still at rudimentary stage. Mostly, Algerian businesses use the platform of Alibaba, which is a Chinese private consortium based in Hangzhou dedicated to e-commerce on the internet, including business-to-business, retail, and consumer sales portals; it also offers online payment services, price comparison search engine, and cloud data storage services (Sharif, 2017).

\section{Introduction}

Djenouhat and Djaouahdou (2016) concluded that Algerian importation from China and the numbers of Algerian's internet users have grown since 2000; moreover, the Algerian import companies have most of e-commerce transaction requirements. It is a fact that the response to these electronic commerce requirements entails potentialities and communication with other companies rather than company's interaction in both internal and external environment. Moreover, it has been acknowledged that each import company has its own capabilities depending on its capital or size. It is on this basis that we investigate the influence of the company's size on electronic commerce transaction requirements.

Assia Djenouhat, doctorate in Sciences, associate professor, Finance \& Commerce Department, Badji Mokhtar University, Annaba, Algeria.

Correspondence concerning this article should be addressed to Assia Djenouhat, Finance \& Commerce Department, Badji Mokhtar University/International trade, FSEG, BP 12, Annaba, Algeria. 


\section{Research Objectives}

- To determine the size of Algerian import companies which trade with China;

- To enumerate the Algerian import companies’ response to EC transaction requirements, according to their size;

- To investigate the impact of company’s size on EC transaction requirement.

\section{Contribution of the Study}

This study will provide essential information for import companies in Algeria that will enhance their awareness and awaken consciousness on the importance of using electronic commerce, rather than increasing their awareness in responding to EC transaction requirements to enable them to trade via e-marketplaces. The findings of the study can also be helpful to academic researchers regarding the further use and development of e-commerce and e-marketplaces.

\section{Literature Review}

E-commerce is the use of electronic communications and digital information processing technology in business transactions to create, transform, and redefine relationships for value creating between or among organizations, and between organizations and individuals (Romulo \& Akhtar, 2003). Based on this, specific companies' components and partners are required to enable good transactions.

\section{Company's Size Concept}

There is no consensus on the definition of companies' size worldwide. This study is conducted under the Algerian context, so it is of importance to make clear the definition of Algerian companies' size. According to their size, companies can be divided into three main sizes: small, medium, and large, where generally small and medium are gathering together under SME (small and medium enterprises).

According to Loi d'orientation sur la PME (2016), SMEs (small and medium enterprises) are defined with four indicators: number of employees less than 250 with annual sales less than two billion Algerian dinars/18.2 million USD, annual balance sheet less than 500 million Algerian dinars/4.5 million USD in condition no more $25 \%$ of the capital must be owned by one or more of companies.

Companies' size can however be defined as follows:

- Small company: number of employees less than 50 with annual sales less than 4.5 million USD;

- Medium company: number of employees from 50 to 249 with annual sales from 4.5 to 18.2 million USD;

- Large company: number of employees more than or equal to 250 with annual sales more than 18.2 million USD.

\section{EC Transaction Requirements}

Business to Business e-commerce as defined by World Trade Organizations (WTO) is "any transaction carried out between organizations in which at least one of the following activities are conducted by electronic media, i.e. production, distribution, marketing, sale or delivery” (Muneesh \& Mamta, 2011).

According to Bauknecht, Bicher, and Proll (2004), companies' e-commerce transaction requirements are split into companies' components and companies' partners.

(1) Companies' components

Electronic commerce requires three companies' components to ensure transactions: corporate website with e-commerce capability, in order not to forward a potential customer to the homepage itself but directly 
transmitting the information which was searched after (Strauss \& Frost, 2014); then, corporate intranet to facilitate information exchange between employees; and finally, IT (information technology)-literate employees which are enable to use information technology for all transactions.

(2) Companies' partners

Electronic commerce requires three companies' partners to ensure transactions: banking institutions that offer transaction clearing services, in order to protect the buyer/the import company and the seller/the export company from financial loss by assuring performing on each contract, without this partner the companies run the risk of physical transfer of cash and securities (Rosenberg, 1996); then, national and international freight companies as a station facilities of a transportation line for receiving and delivering freight, where freight as defined by Rosenberg (1996) is "the sum of fee paid for chartering a ship, or carrying its cargo", without this partner the companies run the risk of shipment; and finally, authentication authority to confirm the identity by validating identity documents, verifying the authenticity of a website with a digital certificate (Turner, 2016).

\section{Methodology}

The methodology for this research was a case study that quantitatively and qualitatively analyzed the data presented in this paper. The population was composed of companies which import several products from China. Yin (2014) suggests that the study case structure is appropriate to research in which the nature of the primary research question involves conclusions regarding "how" or "why" a set of circumstances exists.

\section{Sampling Design}

The author identified 70 companies in Algeria that import several products from China. The studied companies offer many types of products, including clothing and textile, industrial machinery, alimentary products, electrical products and other types. This study measured percentages and means as presented in following tables.

The questionnaire survey technique was used to collect primary data; random probability sampling was employed. The author met with each company in person to deliver the questionnaire. The field study was conducted from March to May 2016. Shmailan (2015) indicated that "sample sizes larger than 30 and less than 500 are appropriate for most research”. Thus, 70 companies were selected as the sample size.

This study attempted to address three research questions, which are described as follows:

- What are the different sizes of the Algerian import companies which trade from China?

- How do Algerian import companies' response to EC transaction requirements according to their size?

- What is the impact of companies' size on EC transaction requirements?

\section{Contribution of the Study}

The results of this study will help companies to understand better electronic commerce transaction requirements, in order to reduce obstacles and support the development of e-commerce in Algeria. It will also be used to gain knowledge for companies' owners to increase trust e-commerce when responding to all companies' components and partners, and encourage trading via e-marketplace. The finding of the study can also aid academic researchers regarding the further development of e-commerce rather than e-marketplace.

\section{Data Analysis and Interpretation}

(1) Introduction 
The primary objective of this study is to determine the size of the Algerian import companies which trade with China; then, to determine the Algerian companies' response to EC transaction requirements according to their size, in which data were collected via survey questionnaire method. Finally, this study aims to demonstrate the impact of companies' size on EC transaction requirements according to descriptive statistic analysis, including percentages and the mean.

The initial research goal is to determine the percentage of companies which import several products from China. The primary reason cited by survey companies' size was the importance of these companies in external trade in Algeria.

Table 1

Sample Perceptions Regarding Size of Company

\begin{tabular}{ll}
\hline Company's size & Percentage \\
\hline Small & $35.72 \%$ \\
Medium & $57.14 \%$ \\
Large & $7.14 \%$ \\
Total & $100 \%$ \\
\hline
\end{tabular}

Table 1 depicts the surveyed companies' size. The majority of studied companies (57.14\%) are medium-sized companies, where $35.72 \%$ are small size, which represent in total $92.86 \%$ of the sample that refer to the big majority of small and medium enterprises (SME) in Algeria due to the government encouragement of this kind of companies' size in all investments. The remaining $7.14 \%$ of studied companies are large-sized companies with big capital which refer to big industries' importation such as industries production unities, building materials and engines, which require large-sized company in terms of human resources, materials, capacity, and area.

The second research goal is to determine the Algerian import companies' response to EC transaction requirements according to their size. The finding indicates the EC transaction requirement was to measure the sample capability in e-commerce, and then, to measure their capability according to their size.

Table 2

Sample Perceptions Regarding Company's Components via Company's Size

\begin{tabular}{lllll}
\hline Components\size & Small & Medium & Large & Total \\
\hline Website & $30 \%$ & $56.25 \%$ & $100 \%$ & $50 \%$ \\
Itranet & $60 \%$ & $56.25 \%$ & $100 \%$ & $64.28 \%$ \\
IT-literate employed & $40 \%$ & $81.25 \%$ & $100 \%$ & $67.85 \%$ \\
Mean & $46.66 \%$ & $64.58 \%$ & $100 \%$ & $60.71 \%$ \\
\hline
\end{tabular}

Table 2 depicts the surveyed companies' components. Based on the e-commerce transaction requirements companies should have all of the three components: corporate website with e-commerce capability, corporate intranet, and IT-literate employees. The mean response of companies' components for all sizes is $60.71 \%$ which means that many of the studied companies respond positively to the companies' components.

As shown in Table 2, for the first requirement, only the half of studied companies have corporate website with e-commerce capability, in which, the less response was for the small-sized companies with only $30 \%$, the remaining $70 \%$ of small companies which represent the majority did not respond to this requirement that means they did not have corporate website. 56.25\% of medium-sized companies respond to website requirement, in 
which the percentage is higher than small size's. The remaining large-sized companies from the studied sample responded totally (100\%) to the first requirement which means all the large-sized companies have corporate website with e-commerce capability. So, the first requirement is influenced by the company's size with direct proportion.

For the second requirement, most studied companies with 64.28\% have corporate intranet, in which, the less response is for medium-sized companies with $56.25 \%$, while the small-sized companies have $60 \%$. The remaining large-sized companies from the studied sample respond totally $(100 \%)$ to the second requirement that means all the large-sized companies have corporate intranet. In the case of corporate intranet, small-sized Algerian import companies find the use of this requirement easier and may facilitate information exchange when coordinating during the transaction proceeding. On the other hand, it is easy to create an intranet with the high technology of software used in most of Algerian import companies. If the company's size is divided into two existing types: the SME and large companies, the second requirement which is corporate intranet is directly proportional with the company's size.

For the third requirement, many studied companies with $67.85 \%$ have information technology and literate employees, only $40 \%$ of small-sized companies' have IT-literate employees while almost medium size with $81.25 \%$ and all of large-sized companies (100\%) have this requirement.

Table 3

Sample Perceptions Regarding Company's Partners via Company’s Size

\begin{tabular}{lllll}
\hline Partners $\backslash$ size & Small & Medium & Large & Total \\
\hline Banking institutions & $40 \%$ & $93.75 \%$ & $100 \%$ & $75 \%$ \\
Freight companies & $30 \%$ & $87.5 \%$ & $100 \%$ & $67.85 \%$ \\
Authentication authority & $50 \%$ & $68.75 \%$ & $100 \%$ & $64.28 \%$ \\
Mean & $40 \%$ & $83.33 \%$ & $100 \%$ & $69.04 \%$ \\
\hline
\end{tabular}

Table 3 depicts the surveyed companies' partners. In line with the e-commerce transaction requirements companies should have all of the three partners: banking institutions that offer transaction clearing services, national and international freight companies, and authentication authority. The mean response of companies' partners for all sizes is $69.04 \%$ which means that almost studied companies respond positively to the companies' partners.

As shown in Table 3, for the first requirement, 75\% of the studied companies have banking institutions that offer transaction clearing services. in which, the less response was for the small-sized companies with only $40 \%$, the remaining $60 \%$ of small companies which represent the majority do not respond to this requirement that means they do not have banking institutions as partners. Almost medium-sized companies with 93.75\% respond to banking institutions requirement; in which the percentage is higher than small size's. The remaining large-sized companies from the studied sample respond totally (100\%) to the first requirement that means all of the large-sized companies have banking institutions that offer transaction clearing services. So, the first requirement is influenced by the company's size with direct proportion.

For the second requirement, the majority of studied companies with $67.85 \%$ have national and international freight companies' partners, in which, the less response is for small-sized companies with $30 \%$, then, medium-sized companies with $87.5 \%$. The remaining large-sized companies from the studied sample respond totally $(100 \%)$ to the second requirement that means all of the large-sized companies have national and 
international freight companies' partners. The second requirement which is national and international freight companies is directly proportional with the company's size.

For the third requirement, much of studied companies with $64.28 \%$ have authentication authority; only 50\% of small-sized companies have authentication authority while almost medium size with $68.75 \%$ and all of large-sized companies (100\%) have this requirement.

Table 4

Sample Perceptions Regarding Company’s EC Transaction Requirements

\begin{tabular}{lllll}
\hline EC transaction requirements $\backslash$ size & Small & Medium & Large & Total \\
\hline Companies' components & $46.66 \%$ & $64.58 \%$ & $100 \%$ & $60.71 \%$ \\
Companies' partners & $40 \%$ & $83.33 \%$ & $100 \%$ & $69.04 \%$ \\
Mean & $43.33 \%$ & $73.95 \%$ & $100 \%$ & $64.87 \%$ \\
\hline
\end{tabular}

As a result of the two precedent tables, Table 4 depicts the company's size positive impact on transaction requirements, the response of the small-sized companies is the lowest with $43.33 \%$, which was followed by the medium size with $73.95 \%$, finally the large size with $100 \%$. It explains the direct proportion demonstrated in Figure 1.

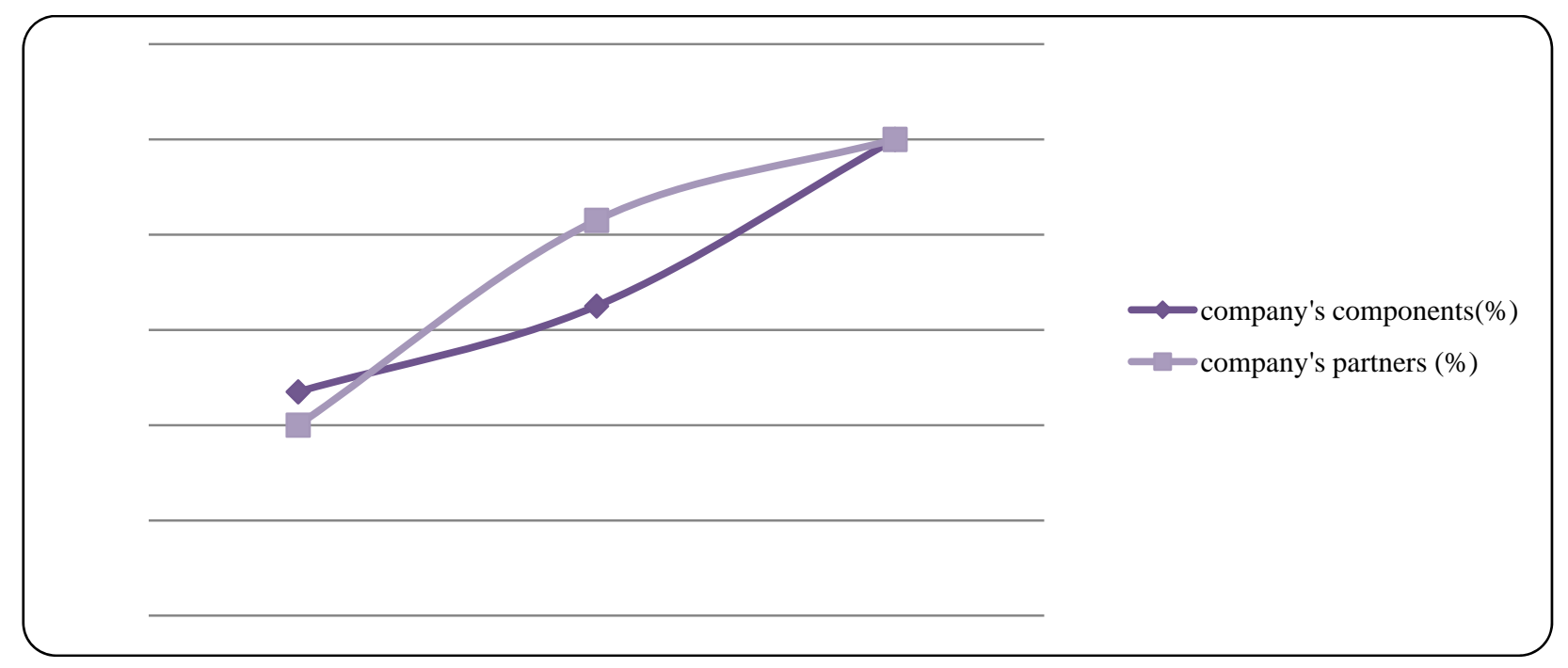

Figure 1. Company's EC transaction requirement via company’s size.

(2) Final results

Data analysis provides the following conclusions:

- The study showed that almost Algerian import companies are SMEs, which represent the company's type, encouraged by Algerian government. The large-sized companies represent industrial companies with import responsible of commercial transaction.

- The study showed that all the Algerian import companies' EC transaction requirements are influenced by the size of the company; the bigger is the size of the company, the higher is its response to EC transaction requirements. So, there is a direct relationship.

- The study showed that company's size has a positive impact on electronic commerce transaction requirement response. 


\section{Discussion}

(1) The study determined the size of Algerian import companies which trade with China. Almost all of the companies are SMEs with $92.86 \%$ while the remaining $7.14 \%$ are large-sized companies. This is because the natures of the imported products from China do not need a large-sized capital company. On the other hand, it is due to the limitation of importation and the government encouragement of local investments in order to produce instead of import.

(2) Besides, the study determined the Algerian import companies' response to EC transaction requirements according to their size. The highest response which is total response is of large-sized companies with $100 \%$; then, medium-sized companies with $73.95 \%$ and finally, the less response is of small-sized companies with 43.33\%. This is due to lack of awareness on the importance of EC transaction requirements rather than the lack of trust on e-commerce. Moreover, almost all the studied small-sized companies are in their earlier age, so they still have no background on external trade especially those who did not have any diploma or certificate on a relative field.

(3) Beyond this, the study demonstrated the impact of companies' size on EC transaction requirements. The impact is positive since the response to all of EC transaction requirements with their both parts companies' components (corporate website, corporate intranet, and IT-literate employees) and companies' partners (banking institutions with transaction cleaning services, national and international freight companies, and authentication authority) accord proportionally with the size of the company.

\section{Conclusion}

This research investigates the impact of companies' size on e-commerce transaction requirements by examining companies' size of Algerian import companies which trade with China, then shows how the size of the company influences the response to EC transaction requirements.

The study surveyed 70 companies which import several products from China. Results show that the majority of the companies are in small- and medium-sized categories, while few are of large size. So, Algerian import companies are still in their early stages of development.

Thus, the impact of companies' size on EC requirements is positive with a direct proportion in both companies' components and companies' partners; the bigger is the size of the company, the higher is its response to each of all the requirements.

In conclusion, the study finds that the positive response to EC transaction requirements is due to the size of the company. Thus, to increase the response to these requirements from SMEs, Algerian direction of commerce and commerce room should focus on enhancing e-commerce use rather than increasing trust on trading via e-marketplaces.

As a result of the development of ITC, innovation, and modernity of trading then the use of e-commerce becomes prominent, given the use of e-commerce in raison international trade and exchange, some of Algerian businesses have metamorphous into the use of e-commerce to enhance their trading with their business partners across the globe. The advent of e-commerce puts it differently, and the revolution of e-commerce in Algeria is highly stimulated by the FDI from China in ICT sector. 


\section{References}

Bauknecht, K., Bicher, M., \& Proll, B., (2004). E-commerce and web technologies. In Proceedings of 5th International Conférence EC-Web 2004, Zaragoza, Spain.

Djenouhat, A., \& Djaouahdou, R. (2016). What extent do Algerian import companies trading via E-marketplace to import from China. International Journal of Development Research, 6(8), 9180-9184.

Loi d'orientation sur la PME. (2016). PME Algérienne, Annuaire Algérien de PME PMI. Available: http://www.pmealgerienne.com/index.php

Muneesh, K., \& Mamta, S. (2011). Trust and technology in B2B E-commerce: Practices and strategies for assurance. AEC, IGI.

Rosenberg, J. M. (1996). Dictionary of international trade. BDS: John Wiley \& Sons, Inc.

Romulo, R., \& Akhtar, S. (2003). E-commerce and E-business, E-Asian Task Force. UNDP, APDIP.

Sharif, S. (2017). Top 10 B2B platforms to help your business grow worldwide. Digital doughnut, 7 July 2017, available: http://www.digitalgoughnut.com/article/2017/july/b2b-platforms-to-help-your-business-grow-globally

Shmailan, A. (2015). The dynamics of online sales for Saudi private organizations in Saudi Arabia. International Journal of E-Business Development, 5(1), 21-36.

Strauss, J., \& Frost, R. (2014). E-marketing (7th ed.). Harlow: Pearson Education Limited.

Turner, D. M. (2016). Digital authentication: The basics.

Yin, R. K. (2014). Case study research: Design and methods (5th ed.). Los Angeles London, New Delhi, Singapore, Washington DC: Sage. 